\title{
10
}

\section{The Khalkha Zaya Pạ̣dita's Smoke Offering Rituals to the Khangai Mountain Range}

\author{
Krisztina Teleki
}

\section{Introduction}

The so-called three lamps of the Géluk tradition, the first eminent Mongolian monks who spread the teachings of the Géluk tradition in Khalkha areas, are Öndör Gegeen Zanabazar (1635-1723), Zaya Paṇita Luvsanprinlei (Qalqa Jaya Bandita Blo bzang 'phrin las, 1642-1719), and Lamiin Gegeen (1639-1704). All of these three authors were born and active in the Khangai region, spreading Buddhist doctrine and rituals. The present chapter aims to introduce the five short, smoke offering ritual texts written by the Khalkha Zaya Pandita (Skrt. jaya "victory"), Luvsanprinlei (1642-1719), who was one of the first Mongolian monks spreading the teachings and practices of the Tibetan Géluk tradition in the Mongol lands. ${ }^{1}$ His collected works (Tib. gsung 'bum), written in Tibetan and printed in Beijing, include a collection of smoke offerings (Mong. san, Tib. bsangs), a number of which are devoted to the Khangai Range and other geographical sites in Sain Noyon Khan Province. ${ }^{2}$

The selected texts exemplify the general structure of smoke offering rituals. The smoke purification offerings in general are intended to pacify and delight celestial beings and the spirit owners or custodians of natural sites such as mountains, rivers, lakes, forests, rocks, and plants, such as lus savdag (Tib. klu sa bdag), gzhi bdag, and naggas. ${ }^{3}$ These rituals encourage them to ensure the well-being and good fortune of the inhabitants of a given region by means of smoke offering purification, especially by detailed ceremonies at the stone or wood cairns (ovoo), which indicate a sacred site. The nomadic Mongols have venerated nature, Father Sky (Tengri) and Mother Earth, and their immediate environment since ancient times. One finds traces of this in Mongolian honorific names for mountains, such as "king" (khan) and "majesty" (khairkhan). In other words, the veneration of mountains and ovoos is a Mongolian practice that precedes Buddhism. ${ }^{4}$ However, the Buddhist form of pacification and propitiation through smoke and other offerings to local spirits of nature began to spread throughout the Mongol territories in the seventeenth century. ${ }^{5}$ 
The five ritual texts translated here demonstrate the accurate use of the Tibetan language by the eminent Mongolian polymath and mirror the spreading of Tibetan rituals in Mongolia.

\section{The Khalkha Zaya Panditita, Luvsanprinlei}

As in the case of other traditional accounts of Mongolian saints and reincarnations (khutugtus and khuvilgaans), it is said that Zaya Pandita's first incarnation lived at the time of Buddha Sākyamuni. The Mongolian tradition holds that four of his incarnations were born in India, three in Tibet, and seven in Mongolia, where they became known as Zyaagin Gegeens ("bright, holiness"). ${ }^{6}$ Certain other sources claim that his ninth incarnation, or the first Mongolian incarnation, was Sain Noyon Khöndlön Tsökhür (1558-1640), a descendant of Chinggis Khan (1162-1227), who met with and paid homage to the Third Dalai Lama, Sönam Gyatso (Bsod nams rgya mtsho, 1543-1588), who bestowed upon him the title of "Zaya Pandita" (Victory Scholar) for his spreading of Buddhism in the Mongol lands. Moreover, since Khöndlön Tsökhür, a layman, Luvsanprinlei (1642-1715), is considered to be the first Mongolian, monastically ordained incarnation in this lineage who descended from Chinggis Khan through the line of Sain Noyon Khans.

Luvsanprinlei received a monastic ordination at the age of three and began to study Buddhism at the age of five. At the age of eleven, he met Öndör Gegeen Zanabazar (1635-1723), the first Buddhist Géluk authority in Mongolia and the First Mongolian Jebtsundamba Khutugtu. After studying from different eminent monks, he went to Tibet in 1660 at the age of eighteen, where he studied until 1679. He received his novice ordination from the Fifth Dalai Lama, Nawang Lobzang Gyatso (Ngag dbang blo bzang rgya mtsho, 1617-1682) and lived primarily in Sera (Se ra) and Tashilhunpo (Bkra shis lhun po) monasteries, where he also met the Fifth Panchen Lama, Lobzang Yeshe (Blo bzang ye shes). The Fifth Dalai Lama bestowed upon him the title of "Zaya Pandita" in 1678 and instructed him to spread Buddhism in the North. After returning home, Luvsanprinlei further developed the already existing monastery that was situated in the foreground of Bulgan Uul (Sable Mountain, currently in the city of Tsetserleg, Arkhangai Province) by building new temples and initiating a monastic system (Mong. deg jayag, Tib. sgrigs bca yig). By 1679, his monastery had five temples and two hundred monks. At this time ceremonies at the monastery began to be performed. However, when the Oirat Galdan Boshugtu (1644?-1696) started to invade the Khalkha territories, important lamas, and many Khalkha nobles were forced to flee to Inner Mongolia. Zaya Pandita was also forced to leave his monastery. From that time on, he taught the Buddhist 
doctrine for Khalkha and Inner Mongolian khans, nobles, and several educated monks. Due to Zaya Paṇita's efforts to put an end to the wars between the Oirat Galdan Boshugtu Khan and Öndör Gegeen Zanabazar, the Qing emperor, Kangxi (1663-1722), granted him the title of "a saint with a seal" (tamgatai khutagt). In 1699, Zaya Pandita founded the temple called Buyaniig Iltgegch Süm ("MeritPreaching Temple") in Höhhot, where monks from Inner Mongolian banners held ceremonies.

Zaya Pạ̣ita's monastery in the foreground of Bulgan Mountain of the Khangai Mountains became well known by the name of its main hall, Buyaniig Delgerüülegch Süm (or Tögs bayasgalant buyaniig delgerüülegch Gandangejeelin, Tib. dga' ldan dge rgyas gling, "Monastery Spreading Blissful Virtue"). He established a library that contained numerous Mongolian, Tibetan, Chinese, and Manchu language Buddhist texts. He died in 1715, but his relics have remained, and even today his restored monastery, Tögs Bayasgalant Buyan Delgerüülekh Süm, has a community of thirty to forty monks.

Zaya Pạ̣dita’s latest incarnation, Luvsandanzan Püljinjigmed (Tib. Blo bzang Bstan 'dzin phul 'byung 'jigs med, born in 1972, was recognized as such by the Fourteenth Dalai Lama in 1999. He actively taught Buddhism in Ulaanbaatar and Arkhangai Province since his passing away in February, 2019.

The Khalkha Zaya Pạ̣ dita was one of the most eminent Mongolian Buddhist scholars and polymaths. He wrote and translated numerous works of different genres, ${ }^{7}$ an encyclopedia of religious studies, biographies, prayers, and texts on incense offerings dedicated to local spirits of several Mongolian sites. Many Mongolian monasteries later followed the regulations and ceremonial system initiated by him; and his monastery became one of the most significant Buddhist centers in Sain Noyon Khan Province, owing to the activities of his later reincarnations.

\section{Collected Works on Smoke Offering Rituals of the Khalkha Zaya Pandita, Luvsanprinlei}

The collected works of the Khalkha Zaya Pandita were printed in Beijing in block print and are kept in several library collections all over the world, one of which is the Library of the Hungarian Academy of Sciences (HAS). ${ }^{8}$ The thirty-first part of his collected works comprises the collection of smoke offering rituals (Tib. bsangs mchod) titled "Precious Garland Smoke Offerings: The Smoke Offerings, Petition Offerings, and Others Compiled by the Shakya Monk Luvsanprinlei” (Shā kya btsun blo bzang 'phrin las kyi/ ngag rnams phyogs su bsgrigs pa las/bsangs chog rin chen phreng ba dang/ bsangs dang gsol mchod la sogs, HAS 237.28/1-16, 
ff. 1-18, Chin. 610-627). Zaya Pandita composed these ritual texts mostly at the request of nobles bearing the ranks of khan, efü, van, gün, and beil who lived in the area of Inner and Outer Mongolia, and some of whom were descendants of Chinggis Khan. The texts were written down by Zaya Pandita’s monastic disciples: Ülemj Biligt, Choijamts, Erdene Güüsh, Shiva Shireet Luvsan, and others. ${ }^{9}$

The collection includes the following sixteen texts, from which texts $4-7$, and 12 are translated here:

1. The Precious Garland of Smoke Offering Rituals (Bsangs kyi cho ga rin po che'i phreng ba), which is an explanation of the smoke offering ritual (bsangs) written at the behest of Dash van of the Kharchin banner (Kha ra chin Bkra shis wang) in 1703 with Agvaanjaltsan Ülemj Biligt (Ngag dbang rgyal mtshan U lem chi Pi lig thu) as a scribe (ff. 1v-6r).

2. Smoke Offering Ritual Blazing with Majestic Brilliance of Accomplishments (Bsangs kyi cho ga dngos grub kyi gzi 'od 'bar ba), which describes a general smoke offering ritual for both mundane and supramundane deities, written at the behest of Jamba Dash gün (Byams pa bkra shis gung) in 1703 with Agvaanjaltsan Ülemj Biligt (Ngag dbang rgyal mtshan U lem chi Bi lig thu) as a scribe (ff. 6r-8r).

3. Smoke Offering Bringing the Rain of Auspiciousness (Bsangs mchod bkra shis char 'bebs), a condensed smoke offering ritual written on the request of a painter, Erdene Biligt Zuraach (Er te ni Pi lig thu ju rā chi), with Choijamts (Chos rgya mtsho) as a scribe (ff. 8r-9v).

4. An untitled text contains an invocation and a prayer ( $g$ sol mchod) for a smoke offering ritual to the mountain deity of Khangai (Hang kas) Mountain and his retinue, to the lord of (Terkhiin) Tsagaan Nuur (presentday Arkhangai Province, Tariat District), and to the lord and spirits of its surroundings. It is written at the behest of Khöndlön van (Khun du lung dbang) (ff. 9v-10r).

5. Invocation and Prayer to the Male Deity Khangai (Pho lha hang kas kyi gsol mchod), which contains an invocation and a prayer for a smoke offering ritual presented to the deity of Khangai (Hang kas) along with his retinue in general and the specific local spirits dwelling at the White Lake (Mtsho dkar, Terkhiin Tsagaan Nuur), "Onnutannu” ('On nu thang nu), ${ }^{10}$ the great mountain Otgon (perhaps, Otgontenger, Od kong ri chen), Ider (E ter), Terkh (Thir khi), Chuluut (Chi lo'u thu), Khasui (Ha su'i), and Tamir (Tha mer), all of which are located mostly in the current area of Arkhangai Province and other sites. It is written at the behest of Yost Erdene Daichin (Yo so thu Er te ni'i ta'i ching) (f. 10r).

6. An untitled text contains a prayer for a smoke offering ritual presented to the mountain deity King Khangai, the protector of the Northern direction 
(byang phyogs skyong ba), and to other deities belonging to his army (sder gtogs), who dwell in a valley (ri lung) and in a hot spring (chu tshan) named Shargaljuut, which release people from their pains. It was composed at the behest of mistress (dpon mo) Danzan Tseveen Ravdan Punyedhara (Bstan 'dzin tshe dbang rab brtan Punyedhara) (ff. 10rv).

7. A Brief Smoke Offering Ritual to the Mighty Deity Khangai (Hang kas lha chen gyi gsol mchod bsdus pa). The Mighty Deity (lha chen) Khangai is also referred to in the text as a "great war-god" (dgra lha chen po) and as a "great commander" (sde dpon chen po). It was written at the request of the fully ordained monk, lovon master (slob dpon) Tunamal Erdene (Thu nu mal Er te ni dge slong) (ff. 10v-11r).

8. An untitled text is a prayer for a libation offering ritual (gser skyems) (ff. 11rv).

9. Smoke Offering Ritual Conferring Accomplishments (Bsangs kyi cho ga dngos grub stsol) is a condensed smoke offering ritual written at the behest of a noblewoman (dpon sa), Dulamjav (Sgrol ma sykabs) (ff. 11v-12v).

10. Pearl Garland Smoke Offering Ritual (Bsangs kyi cho ga mu tig 'phreng $b a)$ is a brief smoke offering ritual, focusing on Vajrabhairava as a visualized deity, for the Dharmapālas in general and for specific local spirits belonging to the retinue of the King of Khentii Mountain (Hen the'i rgyal po), who dwells in the river Kherlen (Khe ru lung), and for the local spirits of the mountains, lakes, forests, springs, and so on. It was composed in 1707 at the behest of Setsen Khan (Se chen rgyal po), a descendant of Chinggis Khan, with Erdene Güüsh, a fully ordained monk (Er te ni gu shrī), as a scribe (ff. $12 \mathrm{v}-14 \mathrm{v}$ ).

11. A Source of Accomplishments Smoke Offering Ritual (Bsangs kyi cho ga dngos grub kun 'byung) describes a smoke offering ritual that uses the power of Vajrabhairava, and that is presented to the local deities and to the mountain, lake, forest, and other deities of Khangai (Hang kas), Otgontenger (Od kong theng ge ri), Orokh (O’u ra has), Shar us (Shi ra u su), Khar us (Ha ra u su), Zavkhan (Tshab hang), Khökh Serkh (Khu khu Ser he Thag), Taishir (Tha'i shi ri), Khasagt (Ha sag thu), Khairkhan (Ha ra Kan), Tsagaan tokhoi (Tsha kān tho ko’i), Daagan del (Tā kang Tel), and other sites. ${ }^{11}$ It was composed at the request of Lamjav beil (Bla ma skyabs be'i le), ${ }^{12}$ a descendant of Chinggis Khan, and his relative Tsetsev ${ }^{13}$ khia taij (Tshe tsheb khyā tha'i ji) (ff. 14v-16r).

12. An untitled text is an explanation of the smoke offering ritual presented to the Mighty Deity (lha chen) Otgontenger (Od hong theng ke ri), the mountain reputed to be the dwelling place of Vajrapanini. It is written at the behest of local leaders ( $d$ pon po) headed by Lamjav beil (Bla ma skyabs pe'i li), a descendant of Chinggis Khan (ff. 16rv). 
13. Smoke Offering Ritual Bringing the Rain of Accomplishments (Bsangs mchod dngos grub char 'bebs) is a smoke offering ritual, with Avalokiteśvara as a visualized deity, dedicated to the Dharmapālas and the like and to the particular local spirits of Zamagt (Tsa mag thu), Tsagaan Chuluut (Tsha kān chi lo’i thu), Khuurai (Ho’a ra’i), Tsagaan Nuur (Tsha kān no kōr), Ünegt (U ne keng), Altat (Al tha thu), Khainag (Ha'i nug), Nomtoi (No mi tha'i), Gün Nuur (Gung Na kōr), Khökh tolgoi (Khe’u khon tho lo ka’i), and other sites. ${ }^{14}$ It was composed as a protective ritual (Tib. sku rim) for Tseren efü (Tshe ring e phu), ${ }^{15}$ a descendant of Chinggis Khan who gave donations (sbyin pa'i bdag po), and for his retinue (ff. 16v-17r).

14. An untitled text is the invocation and prayer ( $g s o l$ mchod) to local protector spirits dwelling at Tsogt Tsagaan Mountain (Tshog thu tsha kan oo la). It was composed at the request of a community of monks headed by Luvsannyam (Blo bzang nyi ma), the younger brother of Yegüzer Khutagt (Bla ma yo ga tsa ra) (ff. 17rv).

15. Smoke Offering Ritual Bestowing the Abundance of All Desires (Bsangs kyi cho ga 'dod rgu'i dpal ster) is a smoke offering ritual presented to the local deities of Khangai (Hang ka'i), Otgontenger (Tib. Od hong theng ke ri), Ider (E ter), ${ }^{16}$ Shumuultai (Sho mo gol tha'i), Khujirt (Hu jir thu), and Angirt (Ang kir thu), as well as to the spirits dwelling in the valleys, lakes, rocks, forests, and springs of Yaruu (Yi ro), Bayan (Ba yang), Agit (A ki thu), Donoi (Do no'i), Usan züil (U sun jul), Khar khad (Ha ra ka thu), Khairkhan (Ha ra kan), Artsat (Ar che thu), Zürkh (Zhu rug), and Tsagaan süul (Tsha kan se kul). It was written at the request of Sūrya Erdene Akhai (Er te ni a ha'i), a son of Erdene Daichin (Er te ni ta'i ching), with Pandita Shireet Tsorj Luvsanshivaa (Shi ge thu chos rje Blo bzang zhi ba) ${ }^{17}$ as a scribe (ff. $17 \mathrm{v}-18 \mathrm{v}$ ).

16. A short prayer belonging to a smoke offering ritual presented to the local spirits (gnas bdag and gzhi bdag) of Dashlin (Bkra shis gling) Monastery (f. $18 \mathrm{v})$.

\section{General Features of the Texts 4-7 and 12}

The five short texts translated here are, as previously mentioned, parts of the "Collection of Smoke Offering Rituals," written by the Khalkha Zaya Pandita (No. 237.28/1-4, 9v-11r) and dedicated to the Khangai Range and nearby localities. In terms of the general structure of the five texts, all begin with blessing or with Sanskrit syllables. After that, in most of these texts, the Khangai King, who in the presence of the Third Dalai Lama, Sönam Gyatso (Bsod nams rgya mtsho, 1543-1588), took a vow to protect the Buddhist teachings, is invited together 
with his retinue. ${ }^{18}$ After that, other local spirits of the given region are invited. The smoke and feast offerings (Tib. tshogs) ${ }^{19}$ of real and imagined offerings are offered to all these celestial guests. Afterward, the Khangai King and all other guests are asked to bring longevity, well-being, and prosperity to the region and to avert obstacles and malevolent spirits who cause troubles. The Khangai King is encouraged to be a protector, ally, and friend of the monastic community and lay devotees when they stay at home, travel, or live in foreign lands. A beautiful prayer for the spreading of the Dharma is repeated at the end of each of these texts. The colophons mention Zaya Pandita Luvsanprinlei as the author; they mention the requesters of the texts and his disciples as scribes. In these texts we find various epithets given to Khalkha Zaya Pandita, such as the "precious rebirth Zaya Pạdita," "the holy one" (e.g., sku skye rin po che dza ya pandi ta hu thug thu), and so on. Similarly, Chinggis Khan is referenced as "the powerful cakravartin, Chinggis Khan," "the physical form of Brahmā" (Tib. stobs kyis 'khor lo bsgyur ba tshangs pa mi'i gzugs can ching gis rgyal po), and so on. We also find here a mention of the two customs, or a dual law (secular and religious laws). All five texts illustrate the ways in which aristocrats and monks honored mountains and waters. In these texts, we also see how the deities of mountains and waters were converted to Buddhism, how they support the spread of the Buddhist doctrine, and how the Khalkha Zaya Pandita spread smoke offering practices at the turn of the seventeenth and eighteenth centuries in the regions of Outer and Inner Mongolia.

\section{The Mighty Khangai King and His Retinue}

Regarding the Khangai mountain range, we cannot find any individual texts written by Öndör Gegeen Zanabazar. ${ }^{20}$ But the previously mentioned Lamiin Gegeen described different aspects of the Khangai in his work A Short Praise of the Khangai King Local Deity (Tib. Khang ka' i rgyal po' i gzhi bdag gi gsol kha shin tu bsdus pa), written in the Tibetan language. ${ }^{21}$ In contrast to the Khalkha Zaya Pạ̣dita, Lamiin Gegeen describes in this text "the Mighty Deity, King Khangai (Tib. Lha chen hang kas rgyal po), the color of whose body is like shimmery sunbeams on a snowy mountain. He holds a five-spoked vajra in his right hand and a pot filled with various goods in his left hand. Precious stones decorate his robes, and he is accompanied by the garuda and another bird. He has the following main attendants. The one on his right side is the Mighty Deity, Golden Khangai (Tib. Lha chen hang kas gser gyi rgyal po), whose body is golden. He wears silken robes and a golden belt and holds shining jewels in his right hand and a silver pot filled with jewels in his left hand. He rides a distinctive, armored horse and is accompanied by demons. The deity on the left 
side of the Mighty Deity, King Khangai, is the Mighty Deity of Power, Khangai King (Tib. Dbang gi lha chen hang kas rgyal po), whose body is like a ruby. He holds a vajra and an iron hook in his right hand and a lasso for catching demons in his left hand. He rides a fast dun horse and is accompanied by a hawk and an eagle. The deity in front of Mighty Khangai is Wild Khangai (Tib. Lha chen hang gas drag po), who is situated on a sun disk. His body is as black as the medicinal eye collyrium. He is fierce, his hair and eyebrows stand up, and his lower lips are pouted. He has four arms; and he holds an axe and a hatchet in his right hands, and the bow and arrows, the lasso and a quiver in his left hands. His demon-like horse is armored. Different attendants accompany him. Lamiin Gegeen's description gives us some idea about the appearance of the deity of the Khangai Range and his retinue, whose pictorial representation is not known at the present time. In this text, Lamiin Gegeen also mentions the flora and fauna of the Khangai Range. ${ }^{22}$

Although the Khalkha Zaya Pạ̣dita does not provide us with a description of the deity of the Khangai Range in his aforementioned texts, ${ }^{23}$ he gives us some clues about this deity by referring to it with different epithets: a divine devotee (Tib. lha'i dge bsnyen), a male deity (Tib. pho lha hang kas), Khangai King or Khangai Majesty (Khangai khairkhan, Tib. Hang ka'i rgyal po), a guardian of the Northern direction (Tib. byang phyogs skyong ba), Mighty Deity, Khangai (Tib. Hang kas lha chen), and Great War-God (Tib. dgra lha chen po). His retinue includes his female consort (a queen) as well as various local gods and spirits who live in the nearby valleys, lakes, and springs.

The Khangai Range, ruled by the Mighty Khangai King, is one of the largest mountain ranges in Mongolia, along with the Altai and Khentii Mountains. ${ }^{24}$ It is a source of many rivers, including the Orkhon, Ider, Zavkhan, and Tamir Rivers. Its flora and fauna are abundant. The most sacred peak of the Khangai Range is Otgontenger ("Youngest deity," 4021 meters high), the veneration of which goes back for centuries. ${ }^{25}$ In Mongolia, the most significant mountain venerations take place at mountain ovoos ${ }^{26}$ and are deemed responsible for the flourishing of the Mongolian State (töriin takhilgatai). At present, ten such mountains ${ }^{27}$ are venerated every fourth or fifth year, including Otgontenger in Zavkhan Province, whose local lord is Vajrapāṇi, and Suvarga Khairkhan ("Stūpa Majesty," 3117 meters high) in Tsenkher district of Arkhangai Province, both of which belong to the Khangai Range. ${ }^{28}$ Apart from these two peaks, other mountains and hills of the Khangai are venerated by local monks and laypeople, such as Bulgan Mountain, which gives a picturesque background to the monastery of the Khalkha Zaya Pandita in the town of Tsetserleg. Interestingly, the prayer of Bulgan Mountain, which is recited in the current monastery on a daily basis, was written only at the time of the Third Zaya Gegeen, Luvsan Jigmeddorj (Blo bzang 'jigs med rdo rje, 1766-1803), whereas the five texts of Zaya Pandita 
translated here seem to be recited only at rare and special occasions, most likely at ovoo venerations in the Khangai Range itself.

\section{Translated Texts}

\section{Invocation and Prayer Belonging to a Smoke Offering Ritual to the Mountain Deity of Khangai}

May it be well! (svasti)

Khangai King, divine devotee, ${ }^{29}$

Who vowed in the presence of the omniscient Sönam Gyatso

To guard the jewel of the doctrine of noble-minded Buddha, ${ }^{30}$

Descend here from celestial realms with your retinue!

Mighty deity, I perform these feast offerings of real and imagined offerings,

Especially this incense-offering that fills the sky for you and for the nagga king who lives

In the auspicious Tsagaan Nuur (White Lake) and who increases people, wealth, and abundance,

For his retinue and the local deities and spirits living in adjoining valleys.

Accept these offerings and pacify all our obstacles and hindrances and those of our companions!

Increase our lifespan, virtues, glory, wealth, and abundance!

Bring the beings of the three realms ${ }^{31}$ under your power!

Subjugate all maleficent beings, enemies, and obstructing spirits!

Be our ally in the unhindered realization of these actions!

May the jewel of the Buddhist doctrine, the source of benefit and happiness spread and flourish!

May the noble holders of the doctrine ever remain!

May the possessions and abundance of the benefactors of the doctrine increase!

May all my wishes come true with your help!

\section{Colophon}

This was written by the incarnation Luvsanprinlei, recognized as Zaya Pandita by the Dalai Lama Vajradhara, ${ }^{32}$ on the request of the powerful hero, the excellent Khöndlön van, a descendant of the powerful cakravartin, Chinggis Khan, a physical form of Brahmā. 


\section{Invocation and Prayer to the Male Deity Khangai}

$H \bar{M} M$.

Great Khangai deity,

Who vowed in the presence of the omniscient Sönam Gyatso

To guard the jewel of the doctrine of the second Buddha, Tsongkhapa,

Descend here, together with your queen and retinue!

Deities, serpent-like beings, demigods, and elemental spirits, ${ }^{33}$

Especially those living in the Tsagaan Nuur, "Onnutannu," Otgontenger;

Ider, Terkh, Chuluut, Khasui, and Tamir Rivers,

In the auspicious Tsagaan Nuur Lake and other places in this region

Gather here and accept this feast offering of real and imagined offerings,

The scent of various burnt smoke offering articles that fill the sky!

Pacify illnesses, negative influences, and all obstacles of ours and our friends in the Dharma!

Increase our lifespan, virtues, glory, and wealth!

Bring the beings of the three realms under your power!

Subjugate all maleficent beings, enemies, and obstructing spirits!

In brief,

Great War-God, support us and our companions continually

When we are staying or going in native and foreign lands!

May you protect and guard us always without weariness!

May the precious Buddhist doctrine, the source of benefit and happiness, spread and flourish!

May the noble holders of the doctrine ever remain!

May these wishes of mine, [who am] a practitioner of yoga, come true spontaneously and effortlessly!

May all be auspicious!

\section{Colophon}

This petition offering to the male deity Khangai was composed by Zaya Pandita in the presence of the encouraging Yost Erdene Daichin, who is adorned with faith and intellect. 


\section{Prayer Belonging to a Smoke Offering Ritual Presented to the Mountain Deity King Khangai}

May it be well! (svasti)

Consecrate the smoke offering articles while repeating three times:

"Smoke offering articles ... OṂ ĀH HŪṂ."34

Héé,

Those who live in the upper and lower parts of the valleys of Tüin and

Shargaljuut,

Who belong to the range (army) of King Khangai, the protector of the North,

Especially deities, nāgas, demigods, regional spirits, local spirits, and all other

Elemental spirits who live in this hot water spring,

It is time to delight you with this feast offering of real and imagined

offerings and

With the scent of the smoke of various, burnt smoke offering articles that reach the clouds.

Enjoy them to your satisfaction!

Eliminate the results of the three poisons cultivated by former actions and current obstacles, ${ }^{35}$

The combination of illnesses of wind, bile, and phlegm, ${ }^{36}$

And the other 404 kinds of diseases ${ }^{37}$ of all the devotees who enter this hot spring!

Make their bodies vital and energetic!

Be the protector, refuge, friend, and aid to those who are effortless

In the realization of awareness and intelligence, [who are] vigorous, firm, and so on, ${ }^{38}$ and [who have] all spiritual qualities and other [good] deeds!

In brief, be our ally and fulfill all of our wishes mentioned in this aspiration!

\section{Colophon}

This was composed by Zaya Pandita Luvsanprinlei on the behest of the lady Danzan Tseveen Ravdan Punyedhara, who has eyes to see the two laws. 


\section{A Brief Smoke Offering Ritual to the Mighty Deity Khangai}

May it be well! (svasti)

HRİM

Great commander deity, Khangai King,

Who vowed to guard the doctrine of Buddha and Tsongkhapa

In the presence of Sönam Gyatso,

The omniscient one who manifested as a saffron-robed monk,

Padmasambhava, the Lotus Born, who is the lord of siddhas,

Avalokiteśvara, the holder of a white lotus, the embodiment of all spiritual leaders,

Descend here from celestial realms with your retinue!

I offer to the Mighty Khangai deity and his retinue

Real and imagined offerings, offering items, ${ }^{39}$ the five sense pleasures,

Offering ritual and golden libation, food, and drink,

And other sacred substances and costly offerings that fill the sky.

I offer to the Mighty Khangai deity and his retinue

This smoke offering of blazing [fire] and a flame of all kinds of incense, ${ }^{40}$

The cloud of various burning smoke offering articles,

Which completely fills the immortal sky.

I praise you, Great War-God,

Who acquired the attitude of subduing anyone with any of the wholesome actions

Of pacifying, enriching, magnetizing, and destroying, ${ }^{41}$

And who guards the doctrine and protects the yogi as your own son.

Mighty Khangai deity and your retinue,

Protect the holders of the doctrine of Tsongkhapa,

The monastic community, and the monasteries!

Pacify all hindrances to the realization of the Dharma, especially [those] of The yogis , masters, and disciples!

Expand their lifespan and increase their merits like the waxing moon!

Gather all beings, properties, and abundance under your power,

And subjugate all maleficent beings, enemies, and obstructing spirits!

Do not forget to be our sentry for three days from afar!

Do not forget to be our sentinel for three nights from near!

Do not forget to be the supreme ally of us,

Of our monastery, people, and properties! 
Even if we are in native or foreign lands, Great War-God, do not leave us alone for a minute! Be the one who welcomes us and who sends us off, Be our accomplice, protector, and refuge, And attract here the excellence and auspiciousness of the ten directions!

May long life, abundance, glory, wealth, reputation, companions, Auspicious goodness, prosperity, Immaculacy, intellect, endeavor, and other attributes of Both the material world and that of the spirit be spontaneously completed!

May the precious Buddhist doctrine, the source of benefit and happiness spread and flourish!

May the noble holders of the doctrine ever remain!

May all immediate and ultimate desires of me, a yogī, come true

In accordance with the Dharma!

\section{Colophon}

This brief petition offering dedicated to the Mighty Khangai deity was written by Zaya Pandita Luvsanprinlei, encouraged by the master of knowledge, the precious master, fully ordained monk, Tunamal Erdene, who said that such a text is essential. May virtuous goodness increase!

\section{Smoke Offering Ritual Presented to the Mighty Deity Otgontenger}

May it be well! (svasti)

If you want to perform a smoke-offering to Otgontenger Mountain,

Reputed to be a dwelling place of Vajrapāni,

Recite the text of taking refuge and arouse the bodhicitta,

Burn offering articles, and sprinkle water reciting the following prayer:

Héé,

Excellent King of protective gods, holder of the northern realm of wealth,

Reputed as Otgontenger,

I invite you and your retinue through the mind!

Gather here without hindrances and take a seat on this pleasing throne!

Accept this immaculate feast offering offered with pleasure!

Pacify all obstacles and hindrances of ours and our companions!

Grant the favorable conditions to us,

Increase our lifespan, merits, glory, and wealth! 
In brief, be with us and our companions

Constantly, without separation for a minute!

Welcome us and send us off, be our protector, refuge, and friend!

Bring here the excellence of the ten directions!

May the precious Buddhist doctrine, the source of benefit and happiness spread and flourish!

May the noble holders of the doctrine ever remain!

May all our immediate and ultimate wishes come true

In accordance with the Dharma!

May the abundance of all that is desired increase as lakes in summer!

May faultless clans be eternal as great rivers of the plains flowing sluggishly!

May all days and nights be spent with Tsongkhapa's teachings!

May all be auspicious with splendor, excellence, and amusement!

\section{Colophon}

It was written by Zaya Pandita Luvsanprinlei at the behest of local leaders headed by the perfectly knowledgeable Lamjav beil, a descendant of the powerful cakravartin, Chinggis Khan, a physical form of Brahmā.

\section{Notes}

1. The present article was written with the support of the János Bolyai Research Scholarship (Bolyai János Kutatási Ösztöndíj) of the Hungarian Academy of Sciences. See Krisztina Teleki, “A Hangáj hegység főbb szövegei, áldozati szövegei," in Szent hegyek a buddhizmusban, edited by Imre Hamar, Zsóka Gelle, and Gábor Kósa, 189208 (Budapest: Bibliotheca Buddhologica Budapestinensis, 2017).

2. Sain Noyon Khan Province was established in 1725, as one of the four Khalkha provinces (others were Tüsheet Khan Province, Zasagt Khan Province, and Setsen Khan Province). Sain Noyon Khan Province was in existence until 1924, and it included certain areas of current Arkhangai, Övörkhangai, Bayankhongor, Khövsgöl, Zavkhan, and Ömnögovi Provinces.

3. Cf. D. Mönkhsaikhan (ed.), Uul ovoonii san takhilgiin sudruud (Ulaanbaatar: Sacred Mongolia Series, 2004). These celestial beings control the ground, animals, plants, and trees; and their influence can be positive or negative. They can turn into various forms or be invisible. There are a thousand types of them; they have kings, queens, officers, generals, slaves, and servants, and they can be males and females. Some of their groups are in Tibetan: klu (serpent-like water spirits, Skr. nāga), sa bdag (earthowing spirits or land lords), gzhi bdag (local deities, lords of the soil), or yul lha (local gods, regional gods, county gods). 
4. See Ágnes Birtalan, "Typology of the Stone Cairns Obos and Their Symbolical Meaning (Preliminary Report, Based on Mongolian Fieldwork Material Collected in 1991-1995)," in Tibetan Mountain Deities: Their Cults and Representations, Proceedings of the 7th Seminar of the International Association for Tibetan Studies, edited by Anne-Marie Blondeau (Vienna: Verlag der Österreichischen Akademie der Wissenschaften, 1998): 199-210; Ágnes Birtalan, "Equestrian Warrior Deities in the Leder Collections. Some Aspects of the Mongolian War God," in The Mongolian Collections Retracing Hans Leder, edited by Maria-Katharina Lang and Stephan Bauer (Vienna: Austrian Academy of Sciences, 2013): 99-110; and D. Mönkhsaikhan (ed.), Uul ovoonii san takhilgiin sudruud (Ulaanbaatar: Sacred Mongolia Series, 2004).

5. For Mongolian smoke offering translations, see Magdalena Tatár, "Two Mongol Texts Concerning the Cult of the Mountains," Acta Orientalia Hungarica 30, no. 1 (1976): 1-58; and Olivér Kápolnás, “Mergen Gegen füstáldozata a Fehér Öreghez," in Tanulmányok: Nyelvtudományi Doktori Iskola, edited by V. Bárdosi (Budapest: ELTE BTK, 2012): 153-166; and Olivér Kápolnás, "Füstáldozat a Tangnu hegyhez" (“Tangnu-yin sang sudur"), in Szent hegyek a buddhizmusban, edited by Imre Hamar, Zsóka Gelle, and Gábor Kósa (Budapest: Bibliotheca Buddhologica Budapestinensis, 2017): 95-112.

6. This part was written based on Zsuzsa Majer and Krisztina Teleki, History of Zaya Gegeenii Khüree, the Monastery of the Khalkha Zaya Pandita (Ulaanbaatar: Admon Printing House, 2013): 15-20. See bibliographical references given in the Bibliography. For biographical details, see also Isabelle Charleux (ed.), History, Architecture and Restoration of Zaya Gegeenii Khüree Monastery in Mongolia (Monaco: Centre d'études mongoles et sibériennes, 2016); and Agata Bareja-Starzyńska, The Biography of the First Khalkha Jebtsundampa Zanabazar by Zaya Pandita Luvsanprinlei (Warsaw: Faculty of Oriental Studies, University of Warsaw, 2015).

7. S. Ishtavkhai, Nom zokhiol tuurvisan mongol lam nariin bürtgel, translated from the original Tibetan by S. Davaabayar (Ulaanbaatar: Publisher unknown, 2006): 19; D. Dashbadrakh, Mongoliin khutagtuud (Ulaanbaatar: Shinjlekh Ukhaany Akademi, Tüükhiin Khüreelen, 2004): 108-109; S. Dorjsüren, Ölzii khutgiin shünshigt nutag (Ulaanbaatar: Publisher unknown, 2007): 12; and J. Ölzii, Mongoliin dursgalt barilgiin tü̈̈khees (Ulaanbaatar: Publisher unknown, 1992): 51.

8. This part is based on the catalogue of the Tibetan manuscripts and block prints preserved at the Hungarian Academy of Sciences. Cf. Gergely Orosz, A Catalogue of the Tibetan Manuscripts and Block Prints in the Library of the Hungarian Academy of Sciences (Budapest: Library of the Hungarian Academy of Sciences, 2008). Mongolian names are given in the transcription of their present-day, Cyrillic form.

9. While it is easy to determine certain geographical sites situated in Sain Noyon Khan Province, several names that appear in the texts cannot be identified.

10. The identification of this name requires further research.

11. The names of some other geographical sites cannot be identified at the present state of research, including Ha la thar, E shi ke, Pa la ka thas, Pur pūd tsha kā kol, Shu rug o la'i tha'i, Ar tsa, Chib tsha Hu ru ma zhi, and Ur thum Tal thu. 
12. Lamjav beil was the leader of Setsen Zasag Banner of Zasagt Khan Province from 1700 to 1731.

13. The Tibetan text says Tshe Tsheb, but Tsetsev as a name does not exist in Mongolia. It requires further research.

14. Some of these geographical names are dubious, and others cannot be identified at the present state of research, including the Big and Small O sa khi, Or chog, Ta pu su thu mcho, A ko lo ko, Tab tha ka'i, Tho'i ri hu, Khang gu rin tha'i, Khu khu to shi, Hang kan tha'i khu' bur hol po, Ha sha lig, and Pūn Na gōr.

15. Tseren efü is an ancestor of the rulers of Setsen Chin Van Banner of Sain Noyon Khan Province. Cf. https://mn.wikipedia.org/wiki/\%D0\%AD\%D1\%84\%D2\%AF_\%D0\% A6\%D1\%8D\%D1\%80\%D1\%8D\%D0\%BD.

16. The names of some other geographical sites cannot be identified at the present state of research, including Chi tur ho co ko lo, Bol tog, A la'i ra kon tsan, The ne thu, $\mathrm{Na}$ o'i kon, The le min, O lo thu, 'U kag ching, Ni zhur hu khu, Hag, Shu lu'i the'i, Chi ger the'i, U li ya tha'i (perhaps Uliastai), Tho bo tsho gas, Hab tha ka'i u lang, Ag rig, Khun dus, Hu ba zher thu, Hu tsha, and Bor ho ther mes.

17. Similarly to Zaya Pandita, Shiva Shireet Luvsan Shivaa, known as the first Shivaa Shireet, was also one of the thirteen high incarnate lamas (khutagt) possessing seals. He was born in Setsen Chin Van's banner in Sain Noyon Khan Province and became famous among the Öölds. Shivaa Shireet's monastery was built in the area of presentday Arkhangai Province.

18. The Mongolian Tümed Altan Khan (1464-1582), a descendent of Chinggis Khan, invited Sönam Gyatso to the Mongol lands (in Inner Mongolia) in 1577 to strengthen the religious connections of the Mongols and Tibetans. This is the official start of the propagation of Gélukpa teachings in the Mongol land. Altan Khan granted Sönam Gyatso the title dalai "ocean," and the institute of the Dalai Lamas came into existence at that time. They confirmed the system of the "two traditions" (secular and religious systems) established by Khubilai Khan and Phagpa Lama in the thirteenth century. Avtai Sain Khan (1554-1588), the ruler of the Khalkhas, participated in this event, and after returning home initiated the building of Erdene Zuu, the first monastery in Outer Mongolia in 1586. The monastery was situated at the eastern edge of the Khangai Range.

19. Regarding the offering articles, a large variety of smoke offering substances exist ( $z a i$, Tib. zas). The most precious incenses (sangiin utlaga) include the three scented ones (gurvan ünerten): juniper (arts), wormwood ( $\left.a g^{\prime}\right)$, and heath (dal'). Incenses with wooden origin can be thyme (ganga), balm (gavar, also gürüm, gügül), red or white sandalwood (zandan), whitish and black aloe (agar), birch (khus), tamarisk (sukhai), and bamboo (khuls). Smoke offerings also can include the medicines of the six good plants (zurgaan sain): nutmeg (zadi), sorghum (jügan), saffron (gürgüm), carnation (lish), sugmel, and gagalo. Apart from incense, other articles can be offered such as jewels, clothing, corps, the three white ones (milk, yogurt, ghee), the three sweets (rock candy, cane sugar, honey), flour, and butter. These substances must not be old, bad, poisonous or smelly. Tormas (balin, Tib. gtor ma) and even weapons and armors can be offered to local spirits as well as the five sense pleasures, the seven royal jewels, the eight auspicious signs, and other precious things. 
20. R. Byambaa and D. Ganzorig, Mongolchuudiin tövd kheleer tuurvisan mongol khelend orchuulsan nom züin bürtgel (Ulaanbaatar: Mongol bilig, 2004).

21. See R. Byambaa and D. Ganzorig, "Mongolchuudiin tövd kheleer tuurvisan mongol khelend orchuulsan nom züin bürtgel," in Mongoliin Burkhan shashinii nomiin ikh Mergediin neg Lamiin gegeen Khanchinchoijil Luvsandanzinjantsangiin Sünbümiin büren garchig orshivoi (Ulaanbaatar: Mongol bilig, 2009): 112. For the Mongolian and English translation of the Dge mtshan bcu ldan lha tshan hang gas rgyal po la bsang mchod 'bul tshul bzhugs so (Smoke Offering to the King Khangai Bearing the Ten Auspicious Signs), see Sükhbaatar (2001): 79-83. The original, Tibetan text was not available at the time of the research. For the present part is the translation of Sükhbaatar's Mongolian translation, see O. Sükhbaatar, "Khangai khanii sangiin sudar," in Lamiin Gegeen Luvsandanzanjantsan (1639-1704). Erdem shinjilgeenii bichig, edited by L. Khürelbaatar (Ulaanbaatar: Publisher unknown, 1998): 82. For War Gods, see Birtalan (2013).

22. Sükhbaatar (1999): 84.

23. Based on Orosz (2008).

24. In the Mongolian language, the word khangai designates a geographical area with mountainous and fertile pastures, which characterize the Khangai region called Khangai Büs. The Khangai Büs includes three provinces at present: Övörkhangai ("Southern Khangai"), Arkhangai ("Northern Khangai"), and Bayankhongor ("Rich Fallow"). The Khangai Range itself covers the northern part of Övörkhangai, the southern part of Arkhangai, and the northern part of Bayankhongor, whereas its highest peak, the famous Otgontenger, is situated in the southern part of Zavkhan Province.

25. It is worshipped by the Mongolian State since 1779. This tradition ceased during the socialist period, but it was revived in 1992. See U. Sarantuyaa and Kh. Tserenbyamba, Nuutsiin Ezen (Ulaanbaatar: Fine Arts Zanabazar Museum, 2015): 21.

26. Ovoo is a stone cairn.

27. Batbold (2012) mentions Bogd Khan Uul, Burkhan Khaldun Uul, Otgontenger Uul, Darigangiin Dar' Ovoo, Altan Khökhii Uul, Suvarga Khairkhan Uul, Khan Khökhii Uul, Sutai Khairkhan Uul, Altai Tavan Bogd, and Gov' Gurvan Saikhan.

28. According to Mongolian legends, the First Zaya Pandita was the first person to venerate this mountain. The Mongolian and English translation of certain smoke offering rituals of Otgontenger and Suvarga Khairkhan are available in Sükhbaatar (2001): 90-95, 174-177.

29. Tib. dge bsnyen; Skr. upāsaka; Modern Mong. buyanii sadan. A Buddhist layman bound by the five Buddhist vows to avoid killing, stealing, lying, sexual misconduct, and intoxicating liquor.

30. Tib. dkon mchog gsum.

31. Tib. khams gsum are the desire realm, form realm, and formless realm.

32. The Fifth Dalai Lama, Losang Gyatso (1617-1682).

33. Tib. lha klu lha min 'byung bo rnams.

34. It might refer to a stanza written in previous smoke-offering texts in the collection.

35. Tib. sngon las 'phral rkyen gyis bskyed dug gsum 'bras. Tib. dug gsum, "the three poisons": attachment, aversion, and ignorance. 
36. Tib. rlung mkhris bad kan (the three main types of illnesses).

37. Tib. bzhi brgya rtsa bzhi nad.

38. Tibetan expression tshu chen cannot be identified.

39. Tib. nyer spyod (flowers, incense, lamps, odors, eatables, etc).

40. Tib. rab 'bar ye shes me nad sna tshogs spos.

41. Tib. 'phrin las bzhi (the four wholesome activities).

\section{Bibliography}

Bareja-Starzyńska, Agata. 2015. The Biography of the First Khalkha Jebtsundampa Zanabazar by Zaya Pandita Luvsanprinlei. Warsaw: Faculty of Oriental Studies, University of Warsaw.

Batbold, D. 2012. Mongol nutgiin 108 shüteen. 108 Sacred Places of Mongolia. Ulaanbaatar: Publisher unknown.

Birtalan, Ágnes. 1998. "Typology of the Stone Cairns Obos and Their Symbolical Meaning (Preliminary Report, Based on Mongolian Fieldwork Material Collected in 1991-1995)." In Tibetan Mountain Deities. Their Cults and Representations, Proceedings of the 7th Seminar of the International Association for Tibetan Studies, edited by Anne-Marie Blondeau, 199-210. Vienna: Verlag der Österreichischen Akademie der Wissenschaften.

Birtalan, Ágnes. 2013. "Equestrian Warrior Deities in the Leder Collections. Some Aspects of the Mongolian War God." In The Mongolian Collections Retracing Hans Leder, edited by Maria-Katharina Lang and Stephan Bauer, 99-110. Vienna: Austrian Academy of Sciences.

Byambaa, R., and Ganzorig, D. 2004. Mongolchuudiin tövd kheleer tuurvisan mongol khelend orchuulsan nom züin bürtgel. (The Bibliographical Guide of Mongolian Writers in Tibetan Language and Mongolian Translations). Ulaanbaatar: Mongol bilig.

Byambaa, R., and Ganzorig, D. 2009. "Mongolchuudiin tövd kheleer tuurvisan mongol khelend orchuulsan nom züin bürtgel." ("The Bibliographical Guide of Mongolian Writers in Tibetan Language and Mongolian Translations"). In Mongoliin Burkhan shashinii nomiin ikh Mergediin neg Lamiin gegeen Khanchinchoijil Luvsandanzinjantsangiin Sünbümiin büren garchig orshivoi (Collected Works of Lamiin Gegeen Khanchinchoijil Luvsandanzinjantsan). Ulaanbaatar: Mongol bilig.

Charleux, Isabelle, ed. 2016. History, Architecture and Restoration of Zaya Gegeenii Khüree Monastery in Mongolia. Monaco: Centre d'études mongoles et sibériennes.

Dashbadrakh, D. 2004. Mongoliin khutagtuud.(Saints of Mongolia). Ulaanbaatar: Shinjlekh Ukhaanii Akademi, Tüükhiin Khüreelen.

Dorjsüren, S. 2007. Ölzii khutgiin shünshigt nutag (My Auspicious and Sacred Land). Ulaanbaatar: Publisher unknown.

Ishtavkhai, S. 2006. Nom zokhiol tuurvisan mongol lam nariin bürtgel (List of Mongol Lama Writers). Translated from the original Tibetan by S. Davaabayar. Ulaanbaatar: Publisher unknown.

Kápolnás, Olivér. 2012. "Mergen Gegen füstáldozata a Fehér Öreghez." (“Mergen Gegen’s Smoke Offering dedicated to the White Old Man”). In Tanulmányok: Nyelvtudományi Doktori Iskola, edited by V. Bárdosi, 153-166. Budapest: ELTE BTK. 
Kápolnás, Olivér. 2017. "Füstáldozat a Tangnu hegyhez” (“Tangnu-yin sang sudur”). In Szent hegyek a buddhizmusban, edited by Imre Hamar, Zsóka Gelle, and Gábor Kósa, 95-112. Budapest: Bibliotheca Buddhologica Budapestinensis.

Khalkha Zaya Pạ̣ita. Collection of Smoke Offering Rituals. Budapest: Hungarian Academy of Sciences (Tib. 237.28/1-16).

Laagan, B. 2004. Khalkhiin tamga bükhii khutagtuudiin tovchis. (Brief Story of Khalkha Saints Possessing Seals). Ulaanbaatar: Publisher unknown.

Majer, Zsuzsa, and Krisztina, Teleki. 2013. History of Zaya Gegeenii Khüree, the Monastery of the Khalkha Zaya Pandita. Ulaanbaatar: Admon.

Mönkhsaikhan, D., ed. 2004. Uul ovoonii san takhilgiin sudruud. (Smoke Offering Texts to Hills and Ovoos). Ulaanbaatar: Sacred Mongolia Series.

Ölzii, J. 1992. Mongoliin dursgalt barilgiin tüükhees (From the History of Mongolian Architecture). Ulaanbaatar: Publisher unknown.

Orosz, Gergely. 2008. A Catalogue of the Tibetan Manuscripts and Block Prints in the Library of the Hungarian Academy of Sciences. Budapest: Library of the Hungarian Academy of Sciences.

Sarantuyaa, U., and Tserenbyamba, Kh. 2015. Nuutsiin Ezen. The Lord of Secrets. Ulaanbaatar: Fine Arts Zanabazar Museum.

Sükhbaatar, O. 1999. "Khangai khanii sangiin sudar” ("Smoke Offering of Khangai Khan"). In Lamiin Gegeen Luvsandanzanjantsan (1639-1704), Erdem shinjilgeenii bichig, edited by L. Khürelbaatar, 79-85. Ulaanbaatar: Publisher unknown.

Sükhbaatar, O. 2001. Mongoliin takhilgat uul usnii sudar orshvoi. (Texts of Venerated Mountains and Waters of Mongolia). Ulaanbaatar: Publisher unknown.

Tatár, Magdalena. 1976. “Two Mongol Texts Concerning the Cult of the Mountains.” Acta Orientalia Hung XXX, no. 1: 1-58.

Teleki, Krisztina. 2017. “A Hangáj hegység főbb szövegei, áldozati szövegei.” ("Main Saints and Sacred Texts of the Khangai Range"). In Szent hegyek a buddhizmusban, edited by Imre Hamar, Zsóka Gelle, and Gábor Kósa, 189-208. Budapest: Bibliotheca Buddhologica Budapestinensis. https://www.budda.mn/news/1282.html https:// mn.wikipedia.org/wiki/\%D0\%AD\%D1\%84\%D2\%AF_\%D0\%A6\%D1 